\title{
Meta analysis: The influence of health education about early marriage to knowledge on teenagers (Review of caution using motion picture, booklet and leaflet)
}

\author{
Ega Ersya Urnia ${ }^{1}$ Meitria Syahadatina Noor ${ }^{2}$, Edi Hartoyo ${ }^{3}$, Eko Suhartono ${ }^{4}$, \\ Pribakti Budinurdjaja ${ }^{5}$ \\ 1, 2, 4 Faculty of Medicine, Lambung Mangkurat Unversity, Banjarbaru, Kalimantan Selatan, Indonesia \\ ${ }^{3}$ Pediatric Health Sciences Specialist of Medical Education Study Program, Lambung Mangkurat Unversity, \\ Banjarbaru, Kalimantan Selatan, Indonesia \\ ${ }^{5}$ Obstetrics and Gynecology Specialist of Medical Education Study Program, Faculty of Medicine, \\ Lambung Mangkurat Unversity, Banjarbaru, Kalimantan Selatan
}

\section{Keywords}

Early marriage

Health education media

Knowledge

Motion picture

Booklet

Leaflet

Received: 15 January 2020

Accepted: 19 March 2020

Published: 16 June 2020

\begin{abstract}
According to data in 2018, 62.67\% of marriages occurred at the age of under 20 years which made South Kalimantan Province ranked first as the province with the highest early age marriage. Early marriage leads to early pregnancy and childbirth, which are associated with high mortality and abnormalities for the mother because a girl's body is not fully mature for childbirth. This study aims to explain the analysis of articles on the effect of providing health education on early childhood marriage using motion picture media, booklets and leaflets in knowledge of adolescents. The research design used was meta-analysis with a pre-post contrast meta-analysis research design. The results of the meta-analysis test of research articles on the effect of providing health education on early age marriage with motion picture media in adolescent knowledge obtained a p-value of $0.0000(<0.005)$, the effect of providing health education on early age marriage with booklet media in Adolescent knowledge obtained a $p$-value of $0.00013(<0.005)$, the effect of providing health education about early marriage with leaflet media in adolescent knowledge obtained a $p$-value of $0.0000(<0.005)$ which means that there is a significant influence between motion picture media, booklets and leaflets with youth knowledge. This research will contribute health promotion policy using useful media. Novel contribution of this research is policy that is more interest for teenagers.
\end{abstract}

(C) 2020 The Author(s). Published by TAF Publishing.

\section{INTRODUCTION}

\section{Background}

Law Number 16 Year 2019 Article 7 concerning Marriage is only permitted if the man and woman have reached the age of 19. Based on the UNICEF report, Indonesia is the country with the seventh highest rate of child marriage in the world, namely 457.6 thousand women aged 20-24 who were married before the age of fifteen $[1,2]$. The 2018 National Basic Health Research data in Indonesia shows that 4.1 percent aged 10-14 years have been pregnant and married and 63.2 percent are pregnant and married at the age of 15-19 years.
Data from Riskesdas South Kalimantan in 2018 shows that 62.67 percent of marriages occur at the age below 20 years, which makes South Kalimantan Province in the first rank as the province with the highest Din-Age Marriage [3]. Early marriage leads to early pregnancy and childbirth, which are associated with high mortality and abnormalities for the mother because a daughter's body is not fully ripe for childbirth. They have fewer opportunities to make decisions in the household and are less able to advocate for themselves or their children. They are also less able to earn income and contribute financially to their families. These

* corresponding author: Meitria Syahadatina Noor

†email: drmeitria@yahoo.com 
things can increase the poverty rate. Marriage at a young age burdens girls with the responsibilities of being a wife, sex partner, and mother, roles that should be done by adults, which are not ready for girls to do. This marriage also imposes a great psychological and emotional burden on them. Young brides experience violence more often $[4,5]$.

According to Hotchkiss et al. [6] risk factors associated with the incidence of early marriage include place of residence (urban or rural), religion, economic status, education level, age at first marriage and intolerance to domestic violence [6]. The results of Windiarti and Besral's [7] meta-analysis research based on analysis from collected journals, it was found that the determinants of early marriage in Indonesia are unwanted pregnancy, peer influence, the role of parents, education level, knowledge of reproductive health, family economic status, culture, and media exposure, while rural residence, region, religion, ethnicity and others show a geographic role [7]. The results of a meta-analysis research conducted by UNICEF in 2011, the determinants of child marriage in Indonesia are also influenced by three aspects. The three aspects are the condition of the individual, household and society. According to UNICEF there is a positive correlation between child marriage and use of the internet via cell phone, the age of the head of the household and the number of children in the family who are in primary school. The results showed that adolescents who have knowledge that women can experience pregnancy when having sexual intercourse are 0.9 times greater than that can prevent themselves from having premarital sexual intercourse. A person who knows that women can experience pregnancy during sexual intercourse can make the decision not to engage in premarital sexual behavior [8].

Knowledge can be increased by providing health education. Health education is a process of changing a dynamic behavior, this change is not just a process of transferring material or theory from one person to another and is not a procedural device, but change occurs because there is awareness from within individuals, groups and society itself. Health education requires the media to maximize the information received by the recipient of the information. Media is something that can transmit messages and can stimulate the thoughts, feelings and abilities of the audience so as to encourage the learning process in themselves. The use of creative media allows the audience to learn better and can improve their performance according to the goals to be achieved [9]. The results of Lestari and Sundayani's [10] study of media motion picture (audio visual/video) greatly affect the increase in knowledge of adolescents about the risks of early marriage [10]. The results of Murtiyarini et al's [11] research show that there is a difference in knowledge about early marriage using booklet media between pretest and posttest [11]. The results of research by Dewi [12] that leaflet media provide increased knowledge about early marriage before and after being given treatment using leaflet media [12].

Furthermore, the researchers conducted a search for research articles on the influence of health education media (motion pictures, booklets and leaflets) on knowledge of adolescent early marriage and it was found that $62.24 \%$ (89 research articles) stated that health education media can change knowledge of adolescent early marriage, while there are $37.76 \%$ (54 research articles) which stated that health education media could not increase knowledge of adolescent early marriage.

From the background above, gaps are found that there is still research that states there is no effect of providing health education with the motion picture method, booklets and leaflets on adolescent knowledge and it is not yet known which methods of health education are good for increasing adolescent knowledge so that researchers intend to know the method. what health education is best used as a medium for providing health education to adolescents by conducting a systematic review of meta-analyzes from various journals and research articles related to meta-analysis.

\section{METHODOLOGY}

The research design used was meta-analysis with a pre-post contrast meta-analysis research design. A form of pre-post comparative research design is to compare the central tendency (eg mean or proportion) on a variable measured at one time with the central tendency on the same variable measured at another time.

Population was all of journal with this research theme (227 journals after online searching). Sample was 25 journals that was already screened with inclusion criterias Inclusion criteria are all aspects that must be present in a study to be reviewed [13]. The inclusion criteria in this study, among others:

a. The study type is quantitative, with a quasi-experimental research design and the test used is the $t$-test.

b. The type of journal used is the original research article.

c. At least 10 main articles to be reviewed, provided the main article must consist of international journals and national journals.

d. Reputable international journals (indexed by Scopus and/or Web of Science).

e. Accredited national journal (indexed Sinta 1 to Sinta 4).

f. Latest articles ( 5 years before) 
g. using data based as follows: SCOPUS, PubMed, and Google Scholar (journal indexed by SINTA 1-4), Garuda Portal (journal indexed by SINTA 1-4) with ten keywords, "early marriage" OR "child marriage" OR "pernikahan usia dini" OR "media pendidikan kesehatan pernikahan usia dini" AND "pengetahuan pernikahan usia dini" OR "sikap pernikahan usia dini" OR "motivasi pernikahan usia dini" AND "media video dan pernikahan usia dini" OR "media booklet dan pernikahan usia dini" OR "media leaflet dan pernikahan usia dini", in English and in Indonesian, as well as the full text.

The independent variable is health education regarding early marriage using motion picture media, booklets and leaflets. The dependent variable is knowledge.

Statistical data analysis was performed computerized by using the SPSS program to perform data analysis with the
Raw Test (unstandardized) mean difference (D) on the effect size and Standardized mean difference ( $\boldsymbol{d}$ and $\boldsymbol{g}$ ) on the effect size. Research uses different measurement methods. These very different measures produce different numerical values which are only meaningful in relation to the operation and the particular scale used [14].

\section{RESULTS}

Based on the screening with the PRISMA diagram, several articles were obtained then selected articles that met the criteria, namely 25 research articles.

\section{A. Unstandardized Mean Difference}

1) Motion Picture: From the results of data analysis in Table 1 , it is found that there is an effect of providing health education with a motion picture on adolescent knowledge with a $p$-value of 0.0000 .

TABLE 1

EFFECT SIZE UNSTANDARDIZED MOTION PICTURE

\begin{tabular}{lll}
\hline \hline & UMD & $\boldsymbol{p}$-Value \\
\hline Fixed Effect Model & 0.166 & 0.0000 \\
Random effect Model & 2.445 & 0.0000 \\
\hline \hline
\end{tabular}

Source: Calculation of research articles with the Meta-Mar application

2) Booklet: From the results of data analysis in Table 2, it is found that there is an effect of providing health education with booklet media on adolescent knowledge with $p$-values of 0.0000 and 0.00013 .

TABLE 2

EFFECT SIZE UNSTANDARDIZED MEAN DIFFERENCE BOOKLET

\begin{tabular}{lll}
\hline \hline & UMD & $\boldsymbol{p}$-Value \\
\hline Fixed Effect Model & 0.146 & 0.0000 \\
Random Effect Model & 1.892 & 0.00013 \\
\hline \hline
\end{tabular}

Source: Calculation of research articles with the Meta-Mar application

3) Leaflet: From the results of data analysis in Table 3, it is found that there is an effect of providing health education with leaflet media on adolescent knowledge with a $p$-value of 0.0000 .

TABLE 3

EFFECT SIZE UNSTANDARDIZED MEAN DIFFERENCE LEAFLET

\begin{tabular}{lll}
\hline \hline & UMD & $\boldsymbol{p}$-Value \\
\hline Fixed Effect Model & 0.146 & 0.0000 \\
Random Effect Model & 1.892 & 0.00013 \\
\hline \hline
\end{tabular}

Source: Calculation of research articles with the Meta-Mar application

\section{B. Standardized Mean Difference}

1) Motion Picture: From the results of data analysis in Table 4 , it is found that there is an effect of providing health education with motion picture media on adolescent knowledge with a $p$-value of 0.0000 . 
TABLE 4

EFFECT SIZE STANDARDIZED MEAN DIFFERENCE MOTION PICTURE

\begin{tabular}{lll}
\hline \hline & SMD & $\boldsymbol{p}$-Value \\
\hline Fixed Effect Model & 4.54 & 0.0000 \\
Random Effect Model & 11.84 & 0.0000 \\
\hline \hline
\end{tabular}

Source: Calculation of research articles with the Meta-Mar application

2) Booklet: From the results of data analysis in Table 5, it is found that there is an effect of providing health education with booklet media on adolescent knowledge with $p$-values of 0.0000 and 0.00013 .

TABLE 5

EFFECT SIZE STANDARDIZED MEAN DIFFERENCE BOOKLET

\begin{tabular}{lll}
\hline \hline & SMD & $\boldsymbol{p}$-Value \\
\hline Fixed Effect Model & 3.53 & 0.0000 \\
Random Effect Model & 7.24 & 0.00013 \\
\hline \hline
\end{tabular}

Source: Calculation of research articles with the Meta-Mar application

3) Leaflet: From the results of data analysis in Table 6, it is found that there is an effect of providing health education with leaflet media on adolescent knowledge with a $p$-value of 0.0000 .

TABLE 6

EFFECT SIZE STANDARDIZED MEAN DIFFERENCE LEAFLET

\begin{tabular}{lll}
\hline \hline & SMD & $\boldsymbol{p}$-Value \\
\hline Fixed Effect Model & 4.85 & 0.0000 \\
Random Effect Model & 8.57 & 0.0000 \\
\hline \hline
\end{tabular}

Source: Calculation of research articles with the Meta-Mar application

\section{DISCUSSION}

\section{A. The Effect of Health Education on Early Childhood Marriage with Motion Picture Media on Knowledge in Adolescents}

The results of the meta-analysis test of research articles on the effect of providing health education on early age marriage with motion picture media on changes in adolescent knowledge obtained a $p$-value of $0.0000(<0.005)$ which means that there is a significant influence between motion picture media and adolescent knowledge.

Before discussing the causes of motion picture media can change adolescent knowledge, it is necessary to know what is meant by knowledge. Knowledge is the result of "knowing" and this occurs after people sensing a certain object. In the sensing process to produce knowledge, it is strongly influenced by the intensity of attention and perception of the object. Knowledge itself is influenced by several factors, including age, education, occupation, social and culture. Knowledge is also very closely related to education where it is hoped that with higher education, the person will be more knowledgeable.12 Adolescents who choose to marry at an early age have low knowledge about the nega- tive effects of early marriage.

The lack of knowledge of adolescents is due to the fact that information has not been conveyed effectively. The effectiveness of information delivery is influenced by the use of the media. In learning, media is needed that can help increase attention and a learning atmosphere. Teens will not feel bored and the message will be conveyed optimally when using interesting media. Media helps the educational process so that it can be captured by the senses. The more senses are used, the clearer knowledge is obtained [15].

Media can be in the form of visual or audio visual. One of the audio visual media is motion picture. A number of studies have shown that audiovisual media can help teaching. Video media uses the senses of sight and hearing. Teens will understand better because they do not only know through lectures but also through moving pictures [15].

Motion picture media is a media that has sound and picture elements. This type has better capabilities, because it includes both auditive (listening) and visual (seeing) media types. Motion picture media is an audiovisual aid which means the materials or tools used in learning situations to assist writing and spoken words in transmitting knowledge, 
attitudes, and ideas [16]. Motion pictures can attract attention, improve motor skills, observe phenomena directly, analyze interactions, issues and problem solving, can be displayed repeatedly, form attitudes, develop appreciation [15].

The advantages of using motion picture media in learning activities are not only as a tool, but as a carrier of information or messages to be conveyed. The use of motion pictures about early childhood marriage can clarify the abstract picture of the importance of maturing age at marriage in adolescents, because in the process of giving the respondent not only hears the material being conveyed, but also sees directly and clearly about the negative impact of early marriage. The benefits of using motion picture (video) media are in accordance with the learning concept according to the experience pyramid written by Edgar Dale, that more than $50 \%$ of people learn from what they have seen and heard [17].

According to the results of research from Lestari \& Sundayani [10] the $p$-value $=0.000$ or $<0.05$ stated that there was an effect of counseling with or without video media on adolescent knowledge about the risks of early marriage [10]. Similar research results were obtained from Kusuma \& Indarjo [18] which showed that there were differences in the level of knowledge about early marriage before and after the film Mancur, obtained a $p$-value $=0.000$ which means $<0.05$. This means that there is a significant difference between the knowledge before and after the screening of the film Mancur [18].

Motion picture media is very often used in various community service activities, according to the results of research by Rohmawati, Hidayah \& Marwan [19] it was found that 60 out of 68 participants experienced increased knowledge about early marriage due to health education using motion picture media [19]. Information media as well as various factors influence the knowledge and behavior changes of adolescents which then affect the behavior of their reproductive health [20]. Adolescents who initially did not understand the negative impacts of early childhood marriage became more aware and understood the dangers or impacts of early marriage [21]. Due to the limited research articles on motion picture health education media, there is no longterm evaluation of the benefits of the health education media.

\section{B. The Effect of Health Education on Early Childhood Marriage with Booklet Media on Knowledge in Ado- lescents}

The results of the meta-analysis of research articles on the effect of providing health education on early age marriage with booklet media on changes in adolescent knowledge obtained a $p$-value of $0.00013(<0.005)$ which means that there is a significant influence between booklet media and adolescent knowledge.

Booklets or pocket books are a useful medium for conveying health messages in sheet form, both in writing and in pictures [11]. It is hoped that health education using booklet media can reduce the rate of early marriage by increasing or maturing the age of marriage. One of the development programs related to population is the Family Planning Program which aims to control the population [15]. The advantages of providing health education with booklet media have advantages because they can be carried everywhere so that they can be read anywhere [11].

According to the results of research from Murtiyarini in 2019 , the $p$-value $=0,000$ or $<0.05$ stated that there was an effect of counseling with booklet media on adolescent knowledge about early marriage. There is limited research that mentions the lack of booklet media so that it is difficult to make comparisons between research results [11].

\section{The Effect of Health Education on Early Childhood Marriage with Leaflet Media on Knowledge in Ado- lescents}

The results of the meta-analysis test of research articles on the effect of providing health education on early childhood marriage with leaflet media on changes in adolescent knowledge obtained a $p$-value of $0.0000(<0.005)$ which means that there is a significant influence between leaflet media and adolescent knowledge. The leaflet method basically has effectiveness in increasing knowledge, this is because the treatment is a method of health education and both are one way (one way method), namely health education and both are active, while the target is passive [12].

The advantage of leaflet media as a source of reproductive health information for adolescents is that it is easy to access, but it needs to be paid close attention to because not all information that is easily accessible has the best quality [12]. Leaflet media was effective in increasing adolescent knowledge and attitudes about health, in SMA Surakarta showed an increase in the mean value of knowledge and attitudes of adolescents from before being given extension treatment with leaflet media compared to after being given extension treatment with leaflet media [22]. 
According to the results of research by Dewi [12], the $p$-value $=0.000$ or $<0.05$, which shows the meaning that there is an influence of extension with leaflet media on adolescent knowledge about early marriage [12]. Similar research results obtained from Elba \& Wijyaya in 2019 obtained a $p$-value $=0.000$ or $<0.05$ which indicates that there is an effect of leaflet media education on adolescent knowledge about early marriage [23].

Basically, adolescents need to be equipped with information about the dangers of early marriage so that they are able to understand the consequences, so that they do not simply take the decision to have an early marriage without knowing the risks [23]. The low knowledge of adolescents has an impact on adolescent sexual behavior towards very dangerous or risky sexual behavior. A person's level of knowledge will affect his psychosocial maturity and thinking ability. The higher the level of knowledge, the easier it is to think rationally, describe and address problems, and make decisions [24]. The presence of various kinds of health educa- tion media for adolescents is expected to be able to increase adolescent knowledge about early marriage. The limited research that mentions the lack of leaflet media makes it difficult to make comparisons between research results for further improvement.

\section{CONCLUSION}

The conclusion from the research results is there is a significant influence between motion picture media, booklets, and leaflets with adolescent knowledge about early marriage, with each $p$-value of 0.0000 for variable motion picture, 0.00013 for variable booklet, and 0.0000 for variable leaflet.

This research had limitation. Journal screening was only for free acces, so researches from payment acces could not be screened. For future research, researcher who will use meta-analysis can try to search in other searching machine that is not free, so they will have more journals to be reviewed.

\section{REFERENCES}

[1] Newacheck PW, Strickland B, Shonkoff JP, Perrin JM, McPherson M, McManus M, et al. An epidemiologic profile of children with special health care needs. Pediatrics. 1998;102(1):117-123. doi: https://doi.org/10.1542/peds.102.1. 117.

[2] Szakaly Z, Peto K. Health behaviour, behaviour change and personalised diet: The concept of lifelong health. Journal of Advances in Health and Medical Sciences. 2018;4(2):43-52. doi: https://doi.org/10.20474/jahms4.2.2.

[3] Adisasmito W, Amir V, Atin A, Megraini A, Kusuma D. Geographic and socioeconomic disparity in cardiovascular risk factors in Indonesia: Analysis of the basic health research 2018. BMC Public Health. 2020;20(1):1-13. doi: https: //doi.org/10.1186/s12889-020-09099-1.

[4] Badan Pusat Statistik. Prevention of Child Marriag; 2016. Available from: https://uni.cf/2V0LPBd.

[5] Niha S, Jantarasiriput B, Tonyongdalaw N, Vaichompu N. Reproductive health among bangoebadae muslim women: Cervical cancer care. International Journal of Health and Medical Sciences. 2016;2(3):52-57. doi: https://doi.org/10. 20469/ijhms.2.30002-3.

[6] Hotchkiss DR, Godha D, Gage AJ, Cappa C. Risk factors associated with the practice of child marriage among Roma girls in Serbia. BMC International Health and Human Rights. 2016;16(1):1-10. doi: https://doi.org/10.1186/ s12914-016-0081-3.

[7] Windiarti S, Besral B. Determinants of early marriage in Indonesia: A systematic review. In: Proceedings of the International Conference on Applied Science and Health, Bandung, Indonesia; 2018. .

[8] Elfi E, Fitrianingsih Y. Effectiveness of Methods Focus Group Discussion (FGD) parental communication in the role of adolescent sexual behavior in Sman 3 Kota Cirebon year 2016. Care: Jurnal Ilmiah Ilmu Kesehatan. 2017;5(3):418-430. doi: https://doi.org/10.33366/cr.v5i3.709.

[9] Mubarak WI. Health Promotion: An Introduction to Teaching and Learning in Education. Yogyakarta, Indonesia: Graha Ilmu; 2007.

[10] Lestari AD, Sundayani L. The effect of extension with video and leaflet media on knowledge and attitudes of adolescents about the risks of early marriage in the Gerung Butun timur environment in 2018. Midwifery Update (MU) Journal. 2020;1(2):79-89.

[11] Murtiyarini I, Nurti T, Sari LA. The effectiveness of health promotion media on adolescent knowledge about maturing age of marriage at public senior high school 9 Jambi City. Journal Health \& Science: Gorontalo Journal Health and Science Community. 2019;1(2):71-78. 
[12] Dewi RK. The Effectiveness of Leaflets and Lectures on the Level of Knowledge About the Risks of Early Marriage at Baturetno Wonogiri High School I in 2017. Stikes Wirahusada Journal. 2017;4(6):45-55.

[13] Mailool J, Retnawati H, Rogahang HJ, Weol W, Waney M. Synthesis and detection of publication bias in relationship between Motivation and teacher performance: A meta-analysis review. Universal Journal of Education and Research. 2020;8(5):6208-62162. doi: https://doi.org/10.13189/ujer.2020.082259.

[14] Retnawati H. Introduction of Meta Analysis. New York, NY: Sage Publications; 2019.

[15] Putri IM, Rosida L. Increasing Knowledge of Marriage Age Maturity Program at Youth Organization Youth Force Salakan Bantul Yogyakarta. Journal of Midwifery Community Service. 2019;1(1):5-11.

[16] Budiman MA. The Effectiveness of Audio Visual Media Assisted Classical Guidance on Early Childhood Marriage. Journal of Indonesian Education Research. 2017;2(2):1-5.

[17] Aeni N, Yuhandini DS. Health education using video media and demonstration methods against knowledge Sadari. Care Journal. 2018;6(2):162-174.

[18] Kusuma FR, Indarjo S. Film mancur (manten kencur) sebagai peningkat pengetahuan dan sikap tentang pernikahan dini. Journal of Health Education. 2017;2(1):53-59.

[19] Rohmawati DL, Hidayah N, Marwan M. Pelatihan konselor teman sebaya dalam upaya peningkatan gizi dan reproduksi pada remaja. Journal of Community Engagement in Health. 2020;3(2):194-199. doi: https://doi.org/10.30994/jceh. v3i2.46.

[20] L MK, Arbimes L. Reproductive Health Education as a Health Promotion Effort at Junior High School 5 Padang city. Scientific Bulletin of Nagari Membangun. 2019;2(1):218-224.

[21] Djanah N, Muaslimah M, Wulan R. Community Service in Promoting Efforts in the Form of Improving the Ability of Young Women About the Marriage Age Maturity Program in Banguntapan Bantul Village. Universal Journal of Educational Research. 2020;1(1):19-25.

[22] Yanti EA. The Effectiveness of Media Leaflet Counseling and Lecture Methods Toward the Knowledge and Attitudes of Students About Early Marriage at Public Senior High School 1 Pancur Batu Deli Serdang in 2019. Colostrum Obstetrics Journal. 2020;1(2):45-69.

[23] Elba F, Wijaya M. The Effect of Providing Reproductive Health Materials About the Dangers of Early Marriage for Young Women. Dharmakarya. 2019;8(1):30-45.

[24] Oktarina J, Marono HM, Purnomo W. The Effect of Peer Reproductive Health Education on Knowledge and Attitudes in Prevention of Premarital Sex at Public Senior High School 1 Sukamara, Sukamara District, Central Kalimantan. Health Systems Research Bulletin. 2017;20(1):34-56. 